EFFECT OF GRID SIZE ON DIGITAL SIMULATION OF GROUND-WATER

FLOW IN THE SOUTHERN HIGH PLAINS OF TEXAS AND NEW MEXICO

By Richard R. Luckey and Diane M. Stephens

U.S. GEOLOGICAL SURVEY

Water-Resources Investigations Report 87-4085

Denver, Colorado

1987 


\author{
DEPARTMENT OF THE INTERIOR \\ DONALD PAUL HODEL, Secretary \\ U.S. GEOLOGICAL SURVEY \\ Dallas L. Peck, Director
}

For additional information write to:

Project Chief Water Resources Division, Central Region

U.S. Geological Survey

Box 25046, Mail Stop 412

Denver Federal Center

Lakewood, CO 80225
Copies of this report can be purchased from:

U.S. Geological Survey Books and Open-File Reports Federal Center, B1dg. 810

Box 25425

Denver, C0 80225 
Abstract-

Introduction--

Purpose and scope-1 4

Approach-- 4

Effect of grid size on predevelopment-period model- 6

Coarse-grid model-a 6

Fine-grid model-16 7

Aggregated mode1-a 16

Effect of grid size on development-period model- 17

Coarse-grid model-_- 19

Fine-grid model-_an 19

Aggregated mode1-. 24

Summary and conclusions- 30

References cited-1 32

\section{FIGURES}

Figure 1. Map showing location of High Plains aquifer and division of aquifer for simulation-- 3

2. Histogram showing differences between simulated and measured predevelopment water levels for the coarse-grid mode1-_....... 7

3. Map showing estimated predevelopment, long-term average recharge rates for the fine-grid model- 9

4. Map showing simulated and measured predevelopment water water levels for the fine-grid model--..-

5. Histogram showing differences in simulated predevelopment water levels between the fine-grid and coarse-grid models--...-.

Page

6. Map showing areal distribution of differences in simulated predevelopment water levels between the fine-grid and coarse-grid models--.-.-

7. Map showing location of nodes with large differences in simulated predevelopment water levels between the



8. Histogram showing differences in simulated predevelopment water levels between the fine-grid and aggregated models--

9. Map showing areal distribution of differences in simulated predevelopment water levels between the

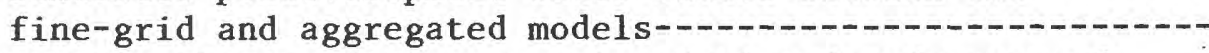

10. Histogram showing differences in simulated and measured 1980 water levels for the coarse-grid model--------

11. Map showing simulated and measured 1980 water levels for the fine-grid model--

12. Histogram showing differences in simulated 1980 water levels between the fine-grid and coarse-grid models------- 
Figure 13. Map showing areal distribution of differences in

simulated 1980 water levels between the fine-grid



14. Map showing location of nodes with large differences in simulated 1980 water levels between the fine-grid and coarse-grid models--..--

15. Histogram showing differences in simulated 1980 water levels between the fine-grid and aggregated models-....-.-.

16. Map showing areal distribution of differences in simulated 1980 water levels between the fine-grid and aggregated models-

\section{TABLES}

Table 1. Model statistics for predevelopment-period calibration of the



Page

2. Simulated predevelopment water level, altitude of base of aquifer, and hydraulic conductivity for nodes with large differences between fine-grid and coarse-grid models--.---.-

3. Water budget for development-period calibration of the fine-grid and coarse-grid models--------

4. Model statistics for development-period calibration of the fine-grid and coarse-grid models-----

5. Simulated 1980 water level and specific yield for nodes
with large differences between fine-grid and coarse-

5. Simulated 1980 water level and specific yield for node
with large differences between fine-grid and coarse-



\section{CONVERSION TABLE}

For use of readers who prefer to use metric (International System) units, conversion factors for inch-pound units used in this report are listed below:

Multiply inch-pount unit

acre-foot

cubic foot per

$$
\text { second }\left(\mathrm{ft}^{3} / \mathrm{s}\right)
$$

foot $(\mathrm{ft})$

foot per day $(\mathrm{ft} / \mathrm{d})$

inch

inch per year (in/yr)

mile (mi)

square mile $\left(\mathrm{mi}^{2}\right)$
By
$1.233 \times 10^{-3}$
$2.832 \times 10^{-2}$
$3.048 \times 10^{-1}$
$3.048 \times 10^{-1}$
$2.540 \times 10^{+1}$
$2.540 \times 10^{+1}$
1.609
2.589

To obtain metric unit

cubic hectometer

cubic meter per second meter

meter per day

millimeter

millimeter per year

kilometer

square kilometer 


\title{
EFFECT OF GRID SIZE ON DIGITAL SIMULATION OF GROUND-WATER FLOW IN THE SOUTHERN HIGH PLAINS OF TEXAS AND NEW MEXICO
}

By Richard R. Luckey and Diane M. Stephens

\begin{abstract}
Three models of the aquifer in the southern High Plains were compared to determine the effect of grid size on simulated water levels. The first model, calibrated prior to this study, had 10-mile grid spacing. The mean difference between the simulated and measured predevelopment water levels in this model was +0.22 foot with a standard deviation of 41.6 feet. For 1980 water levels, the mean difference was +0.28 foot with a standard deviation of 25.8 feet.

The second model, calibrated during this study independently of the first model, had 5-mile grid spacing. The mean difference between the simulated and measured predevelopment water levels was -0.01 foot with a standard deviation of 44.4 feet. For 1980 water levels, the mean difference was +8.22 feet with a standard deviation of 27.9 feet.
\end{abstract}

The results from the first and second models were compared. The standard deviation of the differences in simulated water levels was 19.0 feet for the predevelopment period and 21.8 feet for 1980 . There appeared to be no hydrologic significance to the pattern of the differences.

A third model, constructed by aggregating the data from the second model, had 10-mile grid spacing. The mean difference in simulated predevelopment water levels between the second and third models was +0.86 foot with a standard deviation of 8.9 feet. For the 1980 water levels, the mean difference between the models was +0.39 foot with a standard deviation of 4.4-feet.

The study found that the same hydrologic conclusions would have been reached had 5-mile grid spacing or 10-mile grid spacing been used. It was further concluded that the difference in simulated water levels between models with 5-mile grid spacing or 10-mile grid spacing was five to six times smaller than the differences between the simulated and measured water levels. 


\section{INTRODUCTION}

The High Plains aquifer underlies about $174,000 \mathrm{mi}^{2}$ of the central Great Plains in parts of Colorado, Kansas, Nebraska, New Mexico, Oklahoma, South Dakota, Texas, and Wyoming. More than 20 percent of the irrigated land in the United States overlies the High Plains aquifer, and about 30 percent of the ground water pumped in the United States during 1980 was from the High Plains aquifer (Gutentag and others, 1984, p.7). From predevelopment (the 1930's) to 1980 , over 400 million acre-feet of water have been pumped from the High Plains aquifer (U.S. Geological Survey, 1984, p. 40-41). This pumpage has caused water-level declines that exceeded $10 \mathrm{ft}$ in over $50,000 \mathrm{mi}^{2}$ and exceeded $100 \mathrm{ft}$ in about $3,000 \mathrm{mi}^{2}$ (Luckey and others, 1981).

The U.S. Geological Survey began a study of the High Plains regional aquifer in 1978 (Weeks, 1978). One of the major objectives of the study was to develop computer models to simulate the aquifer system. These models were used to calculate future water levels in response to continued ground-water use.

For the purpose of computer simulation, the High Plains was divided into three parts (fig. 1). The southern High Plains included $29,000 \mathrm{mi}^{2}$ south of about $35^{\circ}$ latitude, the central High Plains included $48,500 \mathrm{mi}^{2}$ between about $35^{\circ}$ and $39^{\circ}$ latitude, and the northern High Plains included $96,500 \mathrm{mi}^{2}$ north of about $39^{\circ}$ latitude. Each of the three parts of the High Plains was simulated separately with a two-dimensional finite-difference model (Trescott and others, 1976) using a regular network of nodes that were spaced $10 \mathrm{mi}$ apart in both the north-south and the east-west directions. There were 303 active nodes in the southern High Plains model, 513 active nodes in the central High Plains model, and 943 active nodes in the northern High Plains model. There was one common node between the southern and central High Plains models and five common nodes between the central and northern High Plains models.

The models were calibrated before they were used to project future water levels. The calibration was done in two phases: (1) A predevelopment-period calibration that simulated the system prior to large-scale irrigation development, and (2) a development-period calibration that simulated the effects of irrigation development on the aquifer system. The calibration consisted of adjusting selected simulated hydrologic properties until the models adequately simulated the historical water levels, water-level changes, base flow to rivers, and cross-boundary flow.

A complete discussion of the geohydrologic setting of the High Plains aquifer is given by Gutentag and others (1984). Detailed versions of the maps in that report provided the input data for the models. The details of model calibration are reported by Luckey and others (1986). A summary of the results of the calibration are repeated in this report in the sections on the coarse-grid model. 


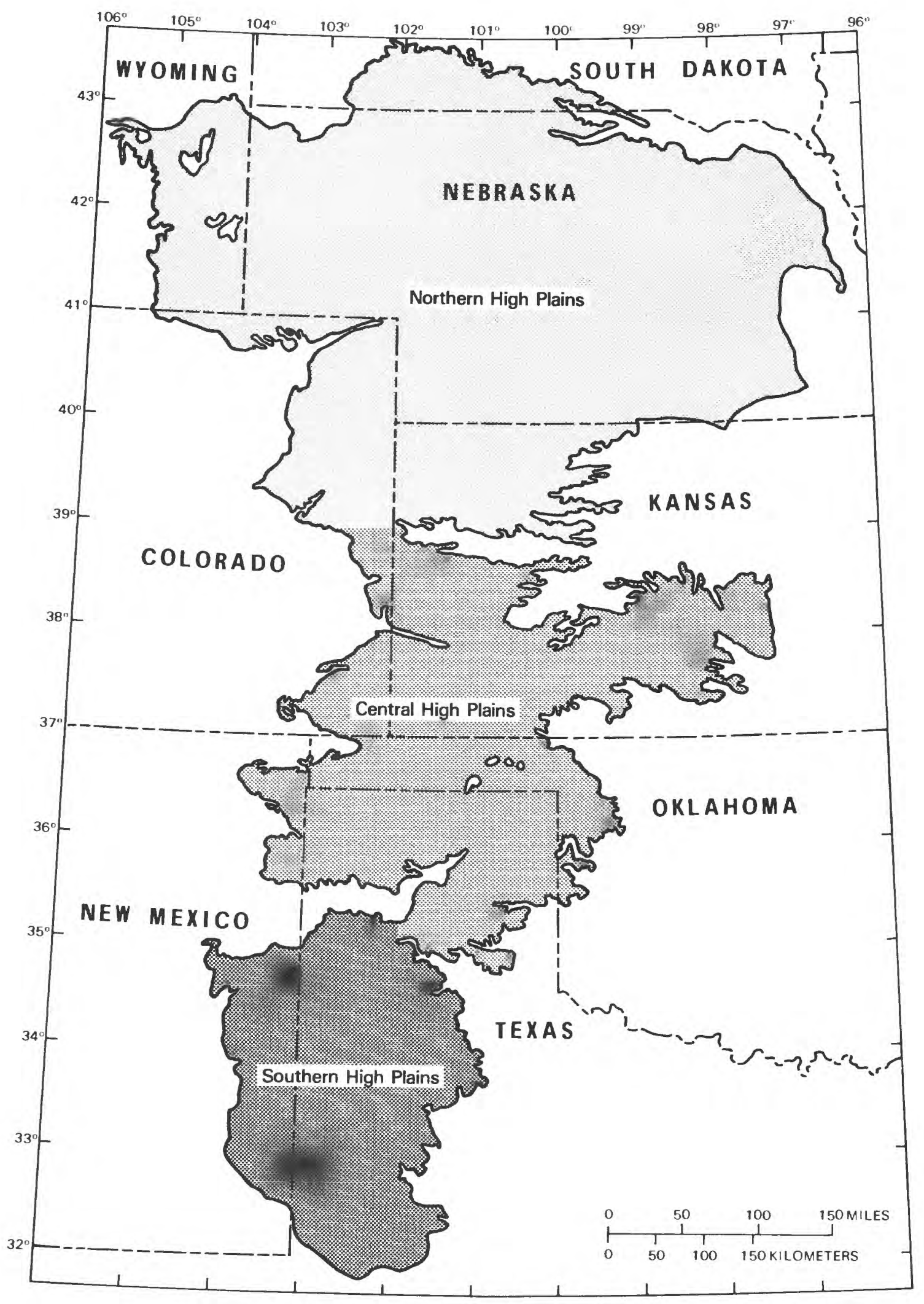

Figure 1.--Location of High Plains aquifer and division of aquifer for simulation. 
This report discusses tests that were conducted to examine the effects of differences in grid spacing on the models of the High Plains aquifer. These tests were conducted to answer two questions: (1) Would a finer model grid have led to a different understanding of the hydrologic system; and (2) how much would the computed water levels (and hence water-level changes) have changed if the model grid were made finer.

The southern High Plains was selected for these tests because it is the smallest of the three parts of the High Plains but has had the largest amount of irrigation development for the longest time. Irrigation development began in the southern High Plains in the $1930^{\prime} \mathrm{s}$, and by 1980 approximately one-half of all water pumped from the High Plains aquifer had been pumped in the southern High Plains. This is despite the fact that the southern High Plains occupies only 17 percent of the total area of the High Plains and contains only 6 percent of the drainable water in storage in the aquifer.

This study attempted to test the new models independently of the previous model (Luckey and others, 1986). However, the insights and conclusions reached in calibrating the previous model undoubtedly had an influence on the tests that were performed in this study.

This study examined different models of the same area constructed by using the same data and two different grid spacings. Hence, this study noted differences in models that were due to both construction and grid size, construction only, and grid size only. All differences are important in answering the two questions posed above.

\section{APPROACH}

The first new model of the southern High Plains was constructed using four times as many nodes as there were in the original model. In this report, the original model, with $100 \mathrm{mi}^{2}$ grids (10-mi node spacing) is called the coarse-grid model. The new model, with $25 \mathrm{mi}^{2}$ grids (5-mi node spacing) is called the fine-grid model. A grid is a rectangular block of a model over which aquifer properties are assumed to be uniform. A node is the point at the center of a grid at which the water level is computed.

A new grid was drawn for the fine-grid model. The grid was drawn such that each grid in the coarse-grid model was represented by four grids in the fine-grid model. This allowed the results of the fine-grid model to be aggregated upward and compared to the results from the coarse-grid model. The fine-grid model could more closely follow the boundary of the aquifer so there were not always four nodes in the fine-grid model corresponding to each node in the coarse-grid model. In a few places, grids in the fine-grid model were outside the coarse-grid model. There were 1,201 active nodes in the fine-grid model and 303 active nodes in the coarse-grid model. 
The data used (see Luckey and others, 1986, p. 3-7) for the fine-grid model were generated from the same original maps that were used to generate the data for the coarse-grid model. These data, in addition to boundary conditions, included initial water levels, hydraulic conductivities, altitudes of the base of the aquifer, specific yields, pumpage, and recharge. Pumpage was estimated by using maps of irrigated acreage and crop consumptive use. Recharge was estimated from various maps (Luckey and others, 1986, p. 10-11). All other data were mapped directly (Gutentag and others, 1984). It is important to note that the data for the fine-grid model were generated from the original maps and not from the data used in the coarse-grid model. As a result, differences in the data (due to visual interpolation) would be expected between the two models, and the different data would result in different results.

Other differences in results between the two models could be expected as a result of the different grid sizes. This difference is called discretization difference in this report. Discretization difference is caused by: (1) Representing aquifer parameters, which are mapped as continuous surfaces, with a series of discrete values; (2) approximating the location of the boundary of the aquifer with a series of lines or points, the location of which is governed by the grid; and (3) substituting finite-difference approximations for the partial derivatives in the ground-water flow equation. The discretization difference between a finite grid and an infinitesimal grid is called the discretization error in this report. It would be impossible to eliminate discretization error, but as the grid spacing becomes progresssively smaller, the discretization error should become smaller until it becomes infinitesimal as the grid spacing approaches zero.

Note that the term discretization error is frequently used in numerical analysis to describe the error from only the third source listed above. In that case, discretization error is synonymous with truncation error. However, in this report, discretization error includes all the errors that occur when a complex system is approximated by finite, discrete areas.

The size of the discretization error is problem dependent. For systems with smoothly varying aquifer parameters and regular boundaries, the discretization error is probably smaller than for systems with rapidly changing aquifer parameters or very irregular boundaries. A finer grid obviously can approximate an irregular surface better than a coarser grid.

To estimate the size of the discretization difference (and hence discretization error) in the model of the aquifer in the southern High Plains, another new model, called the aggregated model, was constructed. The aggregated model could not measure exactly the discretization error, but by comparison with the fine-grid model, could give an indication of the size of the error. The aggregated model had a grid identical to that of the coarse-grid model and simulated parameters as close to those of the fine-grid model as the grid would permit. The values were not identical because it was impossible to represent the aquifer-boundary conditions in exactly the same manner using the $25-\mathrm{mi}^{2}$ and $100-\mathrm{m}^{2}$ grids. The constant-head boundary along the eastern side of the aquifer, which in the model is located at model nodes, 
would necessarily be located at different places in the 5-mi and 10-mi grids. The no-flow boundary around the rest of the aquifer, which in the model is located along model grids, could either be coincident in the two models or could be located at different places.

All of the data from the fine grid model were aggregated from $25-\mathrm{mi}^{2}$ grids to $100-\mathrm{mi}^{2}$ grids by taking the arithmetic average of the values at the fine-grid-model nodes that were within the aggregated-model grid. Finergridmodel nodes that were outside of the original coarse-grid model were ignored. The arithmetic average of the values for the fine-grid model became the values used in the aggregated model.

The differences between the coarse-grid model and the fine-grid model included both differences due to grid size and differences due to having constructed the models independently of each other. The differences between the fine-grid model and the aggregated model would be due only to differences in grid size. The differences between the coarse-grid model and the aggregated model would be due only to the independent construction of the models.

\section{EFFECT OF GRID SIZE ON PREDEVELOPMENT-PERIOD MODEL}

The models were first used to simulate the system prior to large-scale irrigation development. These models were calibrated by adjusting hydraulic conductivity estimates in selected areas and recharge estimates throughout the area to obtain the best correspondence between simulated and historical predevelopment water levels and outflow along the eastern boundary (crossboundary flow). A predevelopment water-level map was constructed using the earliest water-level measurements available in the area. There was only a limited amount of information on predevelopment cross-boundary flow, but what information was available was used to help calibrate the model. After a good correspondence between the shapes of the simulated and measured predevelopment water-level maps was obtained, the models were "fine tuned" by making small adjustments to the average recharge to obtain the minimum mean residual between the simulated and measured water levels.

\section{Coarse-Grid Mode1}

The coarse grid model was used to test various predevelopment recharge patterns to see which produced the best simulated water-level map (as defined above). A pattern with very little recharge over most of the High Plains and more recharge concentrated in the northern part of the area produced the best correspondence between the simulated and measured predevelopment water levels. Recharge in this simulation ranged from 0.086 to $1.03 \mathrm{in} / \mathrm{yr}$ and averaged $0.13-i n / y r$. The total recharge for this simulation was $270 \mathrm{ft}^{3} / \mathrm{s}$. The average cross-boundary flow was $0.71 \mathrm{ft}^{3} / \mathrm{s}$ per mi of boundary.

During the coarse-grid model calibration, it was determined that the hydraulic conductivity had been over-estimated in areas where the original estimates were greater than $50 \mathrm{ft} / \mathrm{d}$. The hydraulic conductivity, as revised during calibration of the coarse grid model, is presented by Gutentag and others (1984, fig. 10). 
The mean difference between the simulated and measured predevelopment water levels at the 303 active nodes in the coarse-grid model was $+0.22 \mathrm{ft}$. The largest differences were $-113 \mathrm{ft}$ and $+99 \mathrm{ft}$. The standard deviation of the differences was $41.6 \mathrm{ft}$ and the mean of the absolute values of the differences was $31.9 \mathrm{ft}$. Ninety percent of the absolute differences were less than $70 \mathrm{ft}$ and eighty percent were less than $55 \mathrm{ft}$. The water levels ranged from more than 5,000 ft to less than 2,600 ft. The saturated thickness ranged from nearly zero to over $200 \mathrm{ft}$. Figure 2 shows the distribution of the differences between the simulated and measured predevelopment water levels for the coarse-grid model.

\section{Fine-Grid Model}

Some of the same recharge patterns that were tested with the coarse-grid model also were tested with the fine-grid model. These included a uniform recharge over the entire southern High Plains and a distribution that increased recharge from south to north. As was the case with the coarse-grid model, these recharge distributions did not provide a satisfactory correspondence between the simulated and measured predevelopment water-level maps.

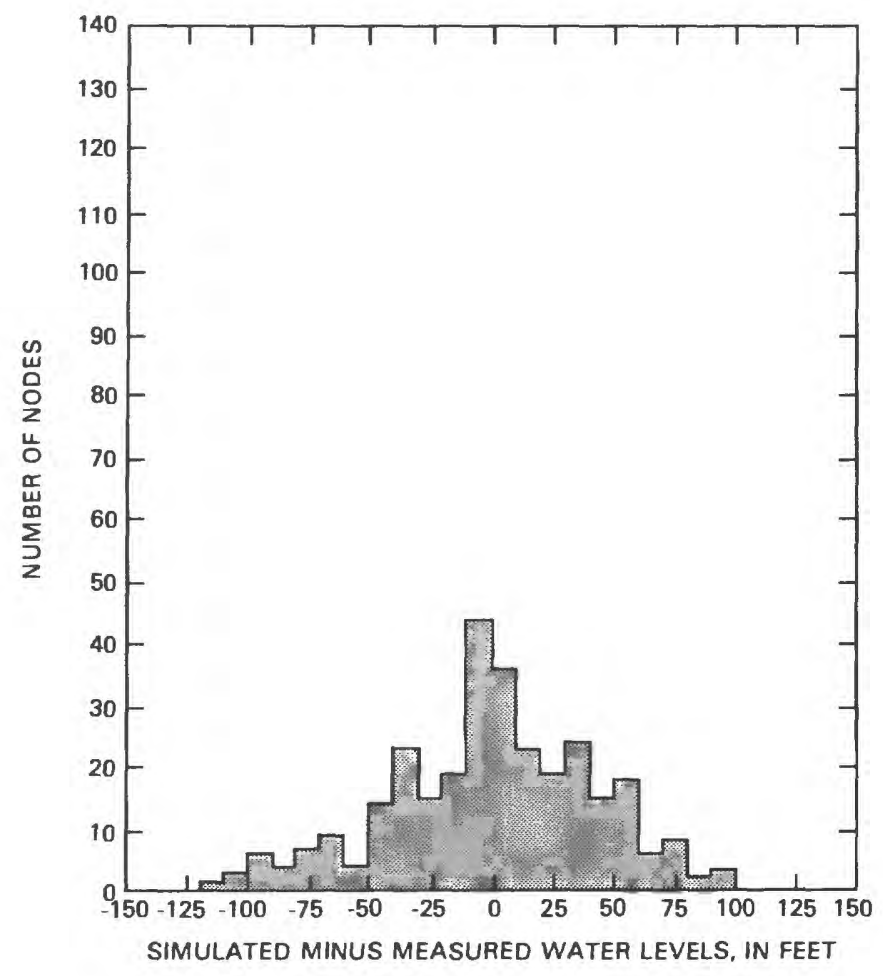

Figure 2.--Differences between simulated and measured predevelopment water levels for the coarse-grid model. 
The hydraulic conductivity estimates, as revised during calibration of the coarse-grid model and presented by Gutentag and others (1984, fig. 10) was not altered during calibration of the fine-grid model.

The recharge distribution that resulted in calibration of the fine-grid model is shown in figure 3. Recharge is concentrated along the Running Water Draw - White River lineaments (Finch and Wright, 1970). The pattern of recharge is identical to that of the coarse-grid model (Luckey and others, 1986, fig. 3), but the values are slightly different. The total recharge was $268 \mathrm{ft}^{3} / \mathrm{s}$. The minimum recharge was $0.084 \mathrm{in} / \mathrm{yr}$; the maximum recharge was $1.004 \mathrm{in} / \mathrm{yr}$; and the average recharge was $0.125 \mathrm{in} / \mathrm{yr}$. The average cross-boundary flow was $0.71 \mathrm{ft}^{3} / \mathrm{s}$ per mi of boundary. The total recharge in the fine-grid model was 0.7 percent less than that for the coarse-grid model while the average recharge was 4 percent less. The percentages for the total and the average are somewhat different because the sizes of the modeled areas are slightly different between the coarse-grid model and the fine-grid model.

Wood and Osterkamp (1984) proposed that much of the recharge to the aquifer in the southern High Plains comes from playa lakes. This concept was not tested with the fine-grid model as it was not known to the authors at the time that the coarse-grid model was calibrated. Because one of the purposes of this study was to determine if different conclusions would have been reached during the original model calibration if a finer grid had been used, it would not have been appropriate to use information not available during calibration of the coarse-grid model. The playa lakes are concentrated in the northern part of the southern High Plains and hence, making recharge a function of playa-lake distribution might result in a recharge distribution similar (or better) to the one that was obtained with the coarse-grid model.

The simulated and measured predevelopment water levels for the fine-grid model are shown in figure 4. There is a reasonable correspondence between the shapes of the contours. The mean difference between the two surfaces at the 1,201 active nodes was $-0.01 \mathrm{ft}$. The minimum difference of $-155 \mathrm{ft}$ occurred at about $35^{\circ} 50^{\prime}$ latitude, $102^{\circ} 50^{\prime}$ longitude; the maximum difference of $+119 \mathrm{ft}$ occurred at about $33^{\circ} 40^{\prime}$ longitude, $103^{\circ} 40^{\prime}$ longitude. The standard deviation of the differences was $44.4 \mathrm{ft}$ and the mean of the absolute values of the differences was $33.4 \mathrm{ft}$. The calibration statistics for both the coarse-grid model and fine-grid model for the predevelopment period are summarized in table 1 .

A sensitivity analysis was done for the predevelopment-period fine-grid model in exactly the same manner as was done for the coarse-grid model (Luckey and others, 1986, p. 47-51). The results of the sensitivity analysis for the fine-grid model were virtually identical to the results for the coarse-grid model. Hence, the results of the sensitivity analysis are not reported here. The similarity of the results of the sensitivity analysis indicated that the coarse-grid model and fine-grid model behave in the same manner, not only at the calibration point, but away from the calibration point.

The simulated predevelopment water levels from the fine-grid model were aggregated by taking the arithmetic average of the simulated water levels at up to four nodes from the fine-grid model that corresponded to one node in the coarse-grid model. This was done so that a node-by-node comparison could be made between the water levels in the fine-grid model and coarse-grid model. 


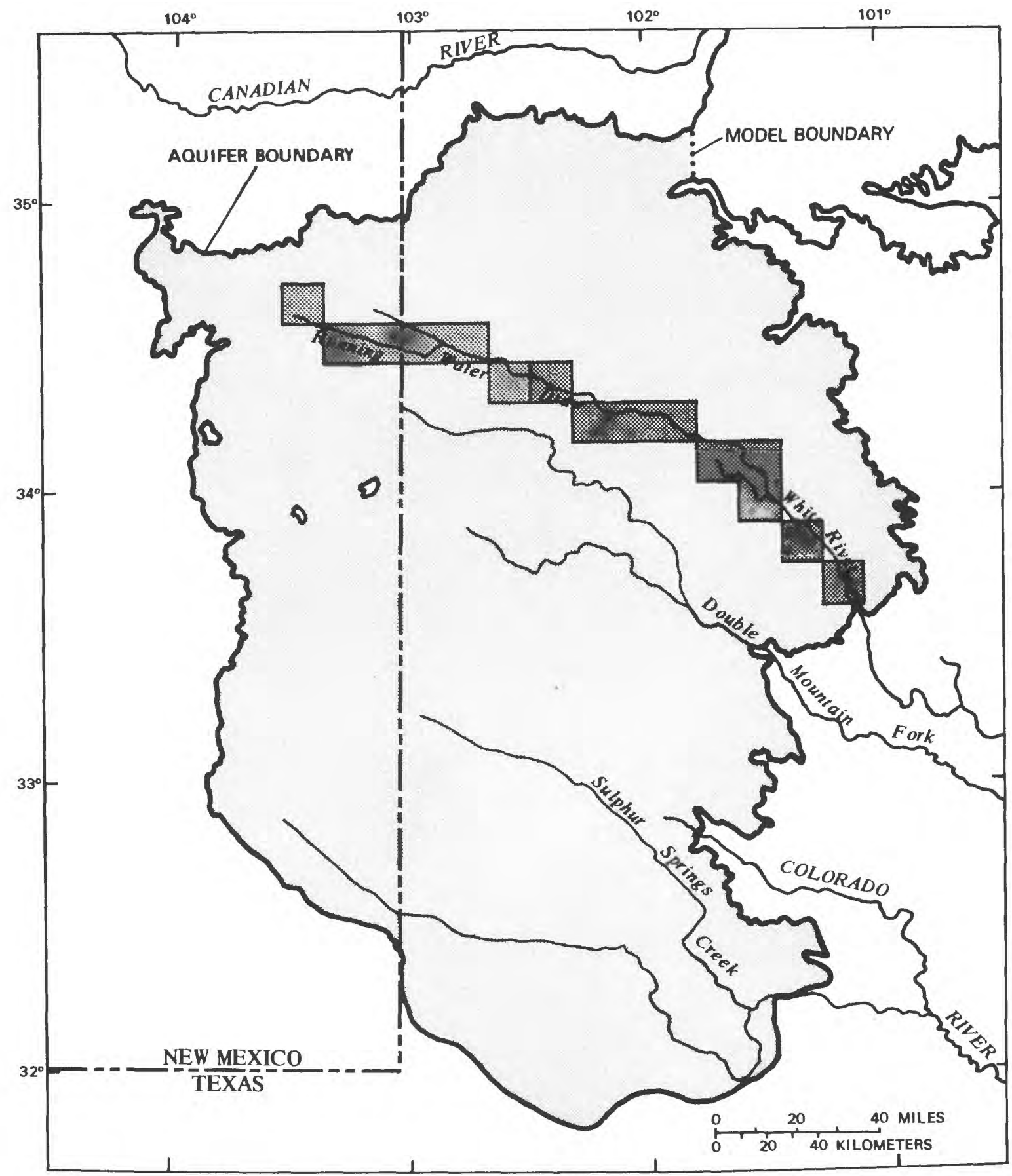

EXPLANATION

RECHARGE, IN INCHES PER YEAR

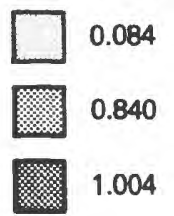

Figure 3.--Estimated predevelopment, long-term average recharge rates for the fine-grid model. 


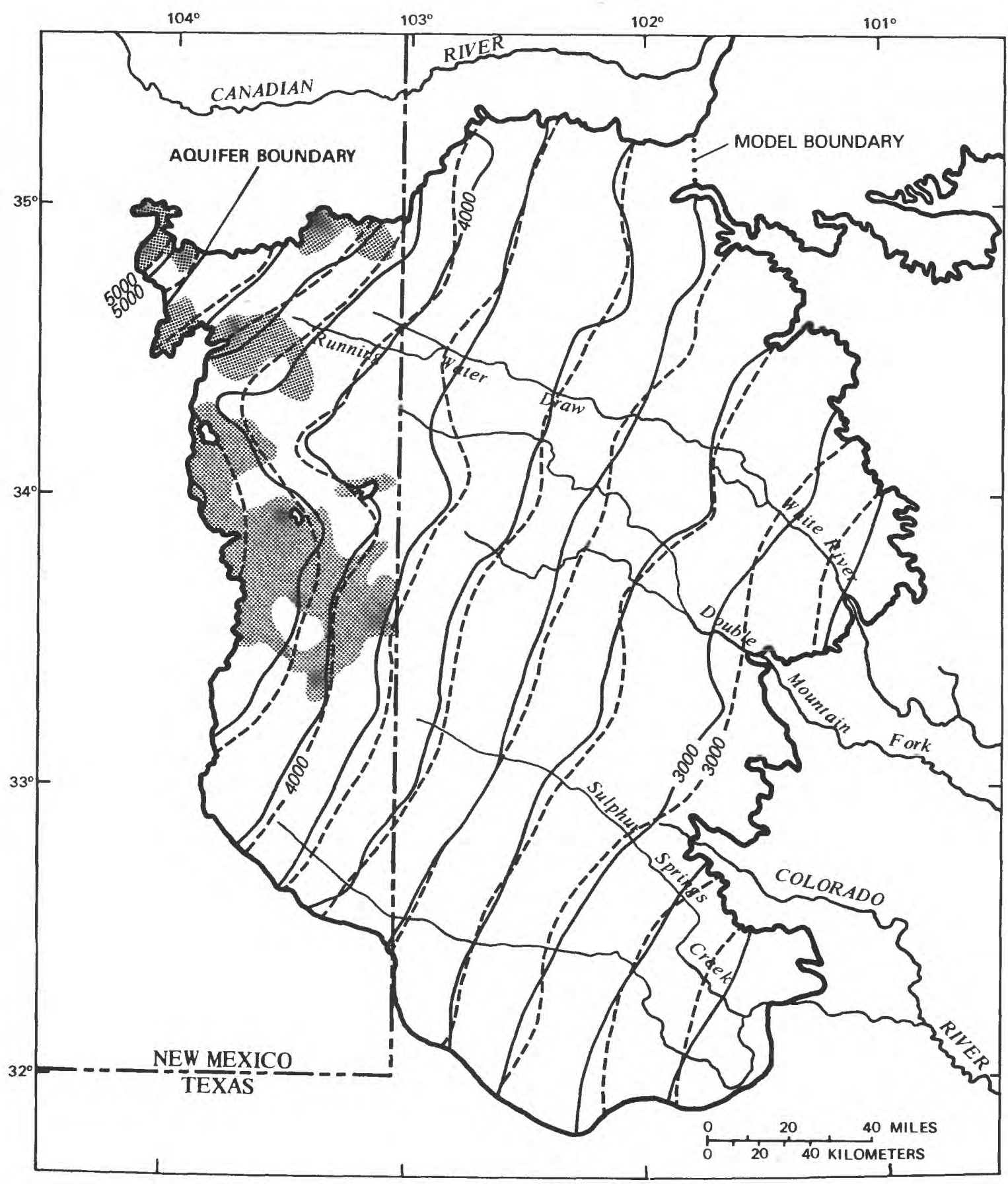

EXPLANATION

AREA OF LITTLE OR NO SATURATED THICKNESS

1980 WATER LEVEL CONTOUR -

Contour interval is 200 feet. Datum is sea level



Figure 4.--Simulated and measured predevelopment water levels for the fine-grid model. 
Table 1.--Model statistics for predevelopment-period calibration of the fine-grid and coarse-grid models

[Units are as indicated]

\begin{tabular}{|c|c|c|}
\hline Statistic & $\begin{array}{l}\text { Fine-grid } \\
\text { model }\end{array}$ & $\begin{array}{l}\text { Coarse-grid } \\
\text { model }\end{array}$ \\
\hline Number of active nodes at & 1201 & 303 \\
\hline Size of node (square miles) & $\begin{array}{r}1,201 \\
25\end{array}$ & 100 \\
\hline Mean difference ${ }^{1}$ (feet) & -0.01 & +0.22 \\
\hline $\begin{array}{l}\text { Standard deviation of } \\
\text { differences } \\
1 \text { (feet) }\end{array}$ & 44.4 & 41.6 \\
\hline $\begin{array}{l}\text { Mean of absolute value of } \\
\text { differences }{ }^{1} \text { (feet) }\end{array}$ & 33.4 & 31.9 \\
\hline Most negative difference ${ }^{1}$ (feet) & -155 & -113 \\
\hline Most positive difference ${ }^{1}$ (feet) & +119 & +99 \\
\hline
\end{tabular}

${ }^{1}$ Difference refers to the measured predevelopment water level minus the simulated predevelopment water level.

The mean difference between the simulated predevelopment water levels for the fine-grid model and the coarse-grid model was $-1.09 \mathrm{ft}$. The standard deviation was $19.0 \mathrm{ft}$.

The distribution of the differences in simulated predevelopment water levels between the fine-grid model and coarse-grid model is shown in figure 5 . As can be seen, 93 percent of the differences between the models were less than $30 \mathrm{ft}$ and 81 percent of the differences were less than $20 \mathrm{ft}$. Two nodes had differences of more than $100 \mathrm{ft}$ and five nodes had differences between 50 and $100 \mathrm{ft}$.

The differences between the simulated water levels from the fine-grid model and coarse-grid model are small compared to the differences between the simulated and measured predevelopment water levels. This can be seen by comparing figure 2 with figure 5. The standard deviation is a statistical measure of the spread of a set of values. The standard deviation of the differences between the simulated and measured predevelopment water levels was $41.6 \mathrm{ft}$ for the coarse-grid model and $44.4 \mathrm{ft}$ for the fine-grid model. These standard deviations are more than twice as large as the standard deviation of the differences in simulated predevelopment water levels between the fine-grid model and coarse-grid model of $19.0 \mathrm{ft}$.

The areal distribution of the differences between the simulated predevelopment water levels for the fine-grid model and coarse-grid model is shown in figure 6. There is a large area of positive difference in the northcentral part of the southern High Plains. The other positive-difference areas are concentrated along the boundary of the aquifer and in areas of little saturated thickness (and hence sparse hydrologic data). There are two large areas of negative difference in the southern one-third of the southern High Plains. Most of these areas fall within the -10 to $-25 \mathrm{ft}$ range. The large 




Figure 5.--Differences in simulated predevelopment water levels between the fine-grid and coarse-grid models.

differences tend to be concentrated in areas of sparse data. The pattern of differences does not seem to be related to either the hydraulic conductivity (Gutentag and others, 1984, fig. 10) or the altitude of the base of aquifer (Gutentag and others, 1984, fig. 6). Hence, no hydrologic significance can be attached to the pattern of differences between these two models.

The simulated predevelopment water levels for the coarse-grid model and fine-grid model for the nodes with the most positive and most negative differences are listed in table 2 and their location is shown in figure 7. These differences are below the fifth percentile and above the ninety-fifth percentile and represent 10 percent of the modeled area. The base of aquifer and the hydraulic conductivity also are shown for these nodes because the simulated predevelopment water levels are sensitive to these two inputs. For some nodes, large differences exist between the model values (for example, the base of aquifer in nodes numbered 28, 29, and 30) but for other nodes the values are similar. These model values are not identical because they were picked independently from each other even though they came from the same original maps. Such differences in visual interpolation are to be expected. When picking values for the fine-grid model, the values used in the coarse-grid model were not consulted to see whether the values for the two models were similar. After the two sets of values were compared, it generally was difficult to determine which set of values more correctly represented the original maps. The difficulty was caused by the wide range of values possible 


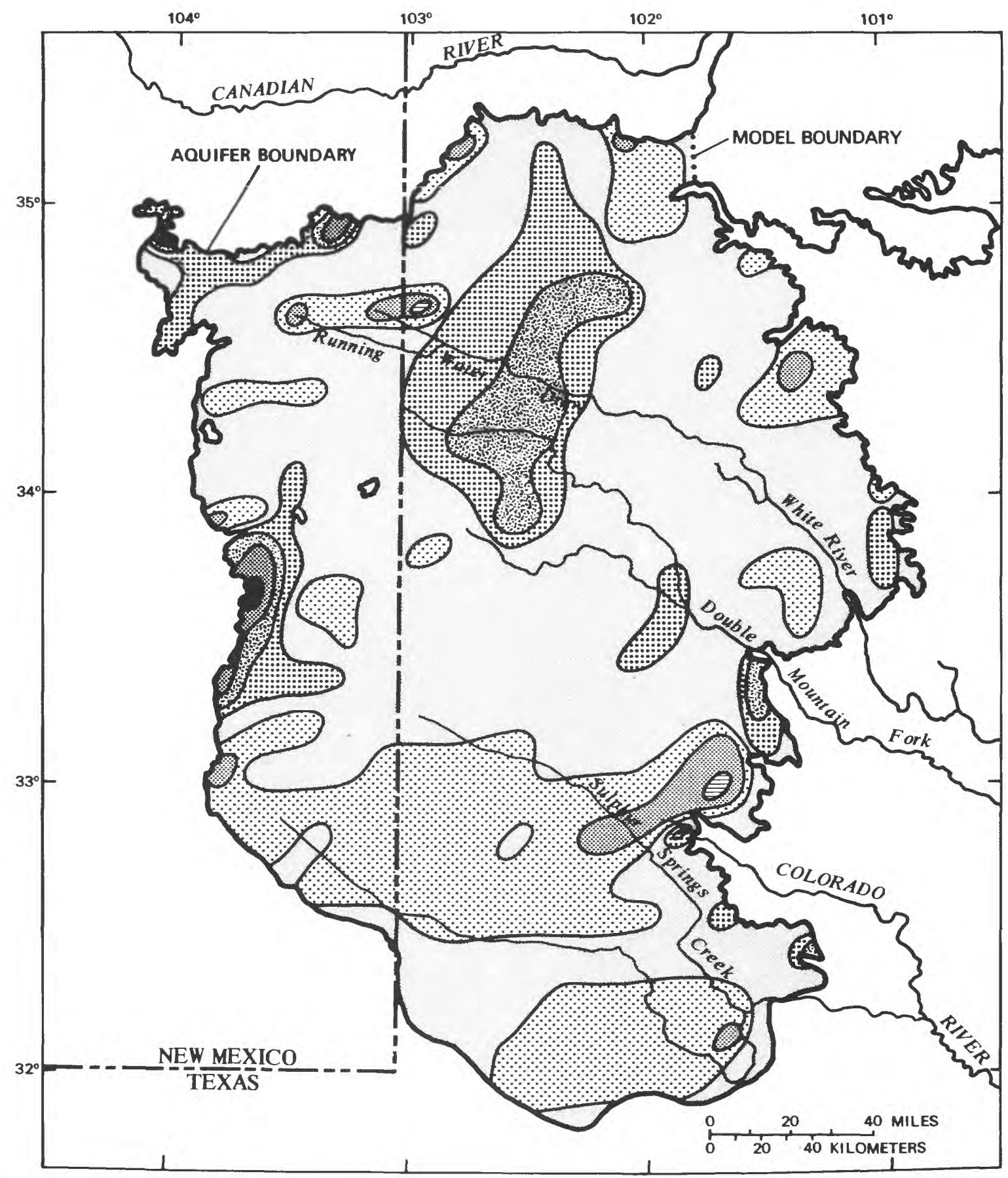

\section{EXPLANATION}

DIFFERENCES IN SIMULATED WATER LEVELS BETWEEN FINE - GRID AND COARSE - GRID MODELS, IN FEET

\begin{tabular}{ll}
\hline Difference more than 100 & 10 to -10 \\
100 to 50 & -10 to -25 \\
50 to 25 & -25 to -50 \\
25 to 10 & Difference less than -50
\end{tabular}

Figure 6.--Areal distribution of differences in simulated predevelopment water levels between the fine-grid and coarse-grid models. 


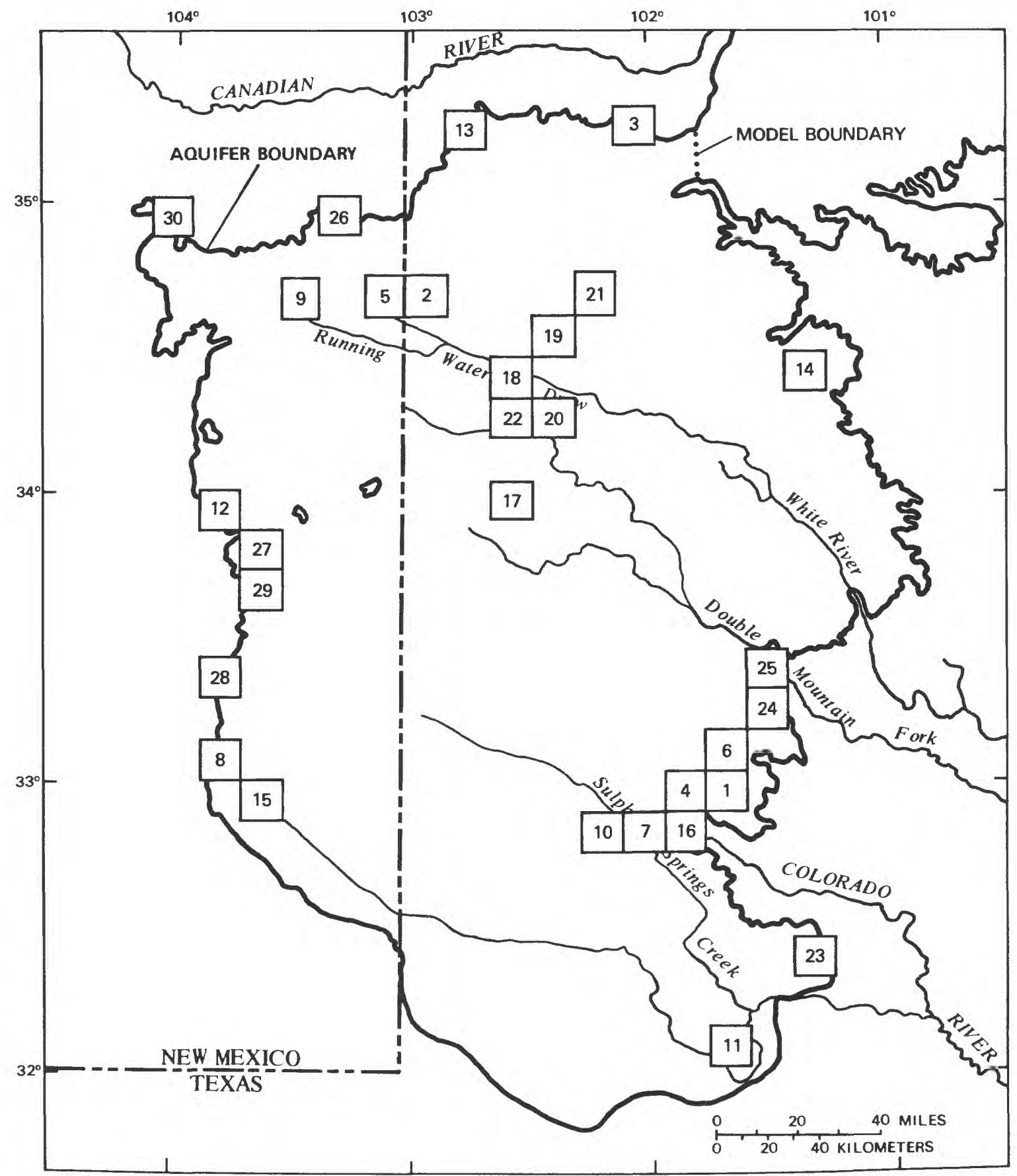

EXPLANATION

16 NODE-Number refers to node in table 2

Figure 7.--Location of nodes with large differences in simulated predevelopment water levels between the fine-grid and coarsegrid models. 


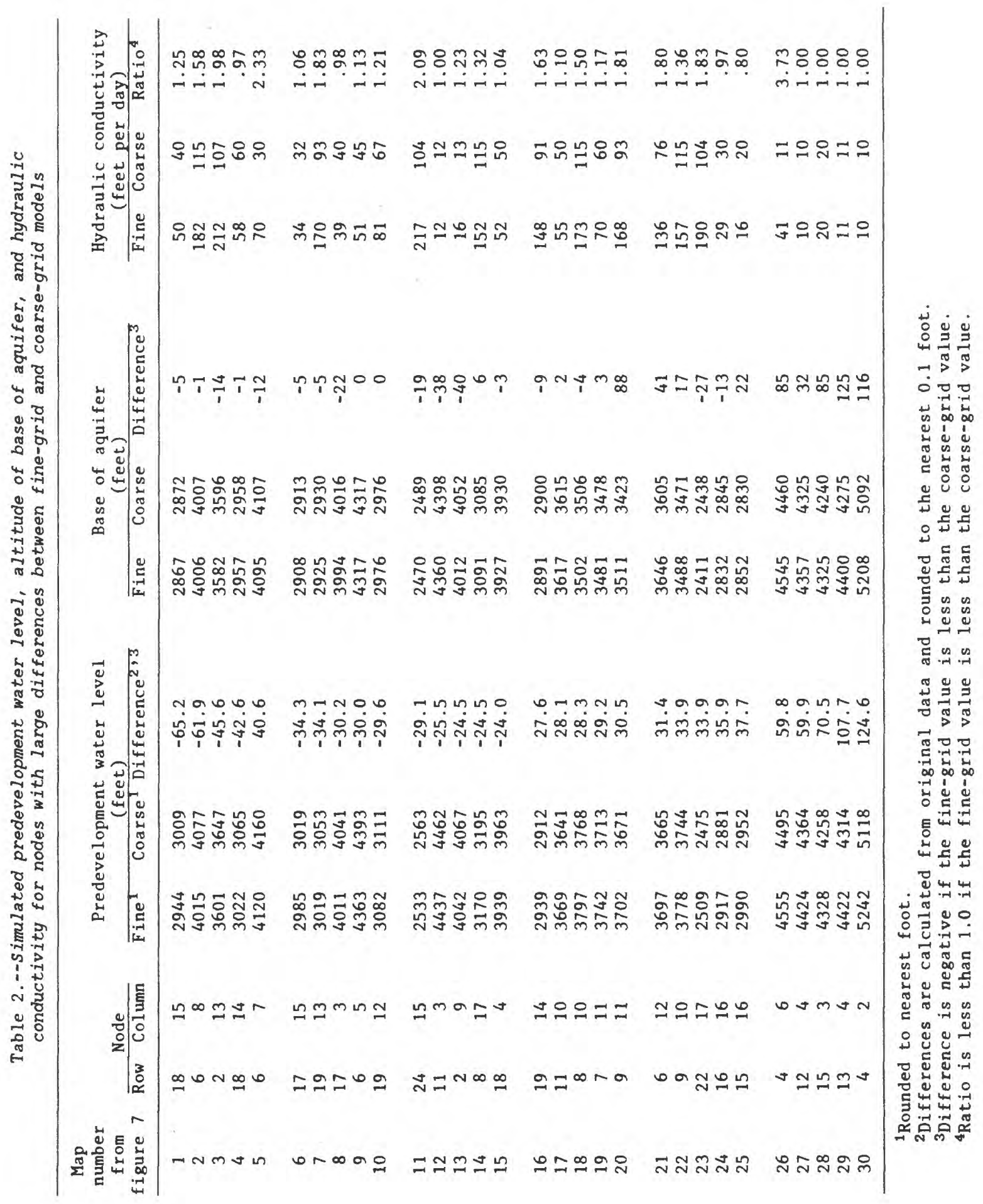


when picking one value to represent $100 \mathrm{mi}^{2}$ or four values, each representing $25 \mathrm{mi}^{2}$. The largest differences, especially for the base of aquifer, occurred at nodes along the boundary in places where the gradient of the base of aquifer changes rapidly.

\section{Aggregated Model}

The predevelopment-period aggregated model was used to calculate the predevelopment water level using a $100 \mathrm{mi}^{2}$ grid. The aggregated model had 303 active nodes. Model inputs were not changed during this simulation.

The simulated predevelopment water levels for the fine-grid model were compared for those nodes in the aggregated model which had four corresponding nodes in the fine-grid model. The comparison was made by subtracting the mean of the four fine-grid-model water levels from the corresponding aggregated-model water level. These differences are an estimate of the discretization difference between $25-\mathrm{mi}^{2}$ and $100-\mathrm{mi}^{2}$ grids. A histogram of the differences in simulated predevelopment water levels between the fine-grid model and aggregated model is shown in figure 8 . The differences ranged from $-35 \mathrm{ft}$ to $+36 \mathrm{ft}$ and averaged $0.86 \mathrm{ft}$ for the 278 nodes in the aggregated model that had four corresponding nodes in the fine-grid model. The standard deviation of the differences was $8.9 \mathrm{ft}$. Ninety percent of the nodes had differences of less than $15 \mathrm{ft}$ and eighty percent had differences of less than $10 \mathrm{ft}$. Comparing this histogram to figure 2 shows that the discretization difference between the $25-\mathrm{mi}^{2}$ and $100-\mathrm{mi}^{2}$ grids is small compared to the difference between the simulated and measured predevelopment water levels. The differences between the coarse-grid model and the fine-grid model were caused both by differences in model inputs and by discretization difference. This histogram (fig. 8) shows much smaller differences than the differences between the coarse-grid model and the fine-grid model (fig. 5). This indicates that much of the difference between the coarse-grid model and the fine-grid model was due to differences in the values picked for the model rather than discretization error.

The areal distribution of the differences in simulated predevelopment water levels between the fine-grid model and aggregated model is shown in figure 9. Over much of the southern High Plains, the differences between these models were less than $5 \mathrm{ft}$. All of the differences greater than $20 \mathrm{ft}$ were concentrated along the boundary of the aquifer. This indicates that for these models, a large part of the discretization difference was caused by different approximations of the location of the boundary of the aquifer. There is a fairly large area away from the boundary of the aquifer at about $33^{\circ}$ latitude with -5 to $-10 \mathrm{ft}$ differences. This area contains three smaller areas of -10 to $-20 \mathrm{ft}$ differences. At about $34^{\circ}$ latitude, an area of +5 to $+10 \mathrm{ft}$ differences away from the boundary contains a smaller area of +10 to $+20 \mathrm{ft}$ difference. These areas both correspond to areas where the hydraulic conductivity map (a detailed version of figure 10 in Gutentag and others, 1984) indicated large changes in hydraulic conductivity over fairly small distances. For example, in the northern area, hydraulic conductivity changed from 15 to $75 \mathrm{ft} / \mathrm{d}$ in about $10 \mathrm{mi}$ in one place and in the southern area, it changed from 25 to $160 \mathrm{ft} / \mathrm{d}$ in about the same distance. This was a 


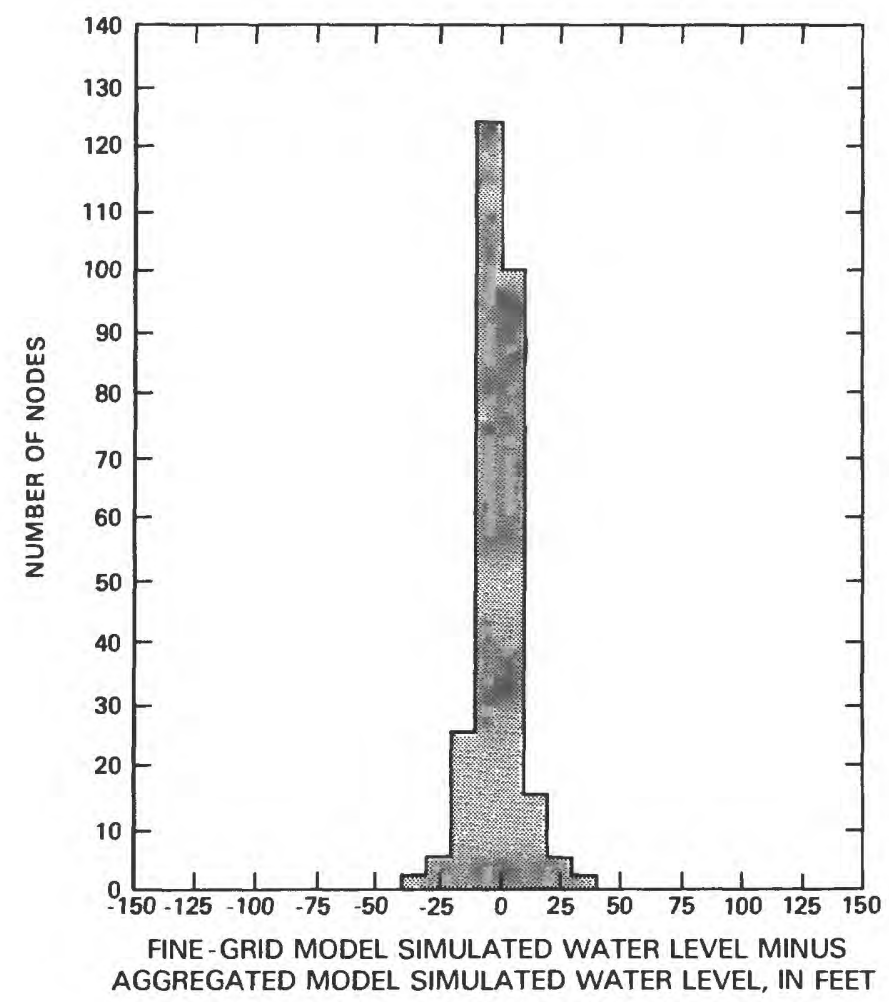

Figure 8.--Differences in simulated predevelopment water levels between the fine-grid and aggregated models.

five- to six-fold change. In these areas, the discretization difference could be due to approximating the ground-water flow equation with a finitedifference equation or representing the hydraulic conductivity with a series of discrete values.

The aggregated model also was tested using the geometrically averaged (rather than arithmetically averaged) hydraulic conductivity. The areal distribution of water levels was virtually identical to that obtained using the arithmetic average. The histogram of water-level differences between this model and the fine-grid model showed a skew to the right with a mean difference of $3.44 \mathrm{ft}$. Because of this bias and little difference in distribution of differences between the models, the aggregated model used the arithmetically averaged hydraulic conductivity to estimate discretization error.

\section{EFFECT OF GRID SIZE ON DEVELOPMENT-PERIOD MODEL}

The effects of irrigation development on the aquifer in the southern High Plains was simulated using the models. These models began with the predevelopment (1940) water level and were calibrated by comparing the simulated and measured 1980 water-levels. The primary new stress on the aquifer in the southern High Plains after 1940 was the withdrawal of large 


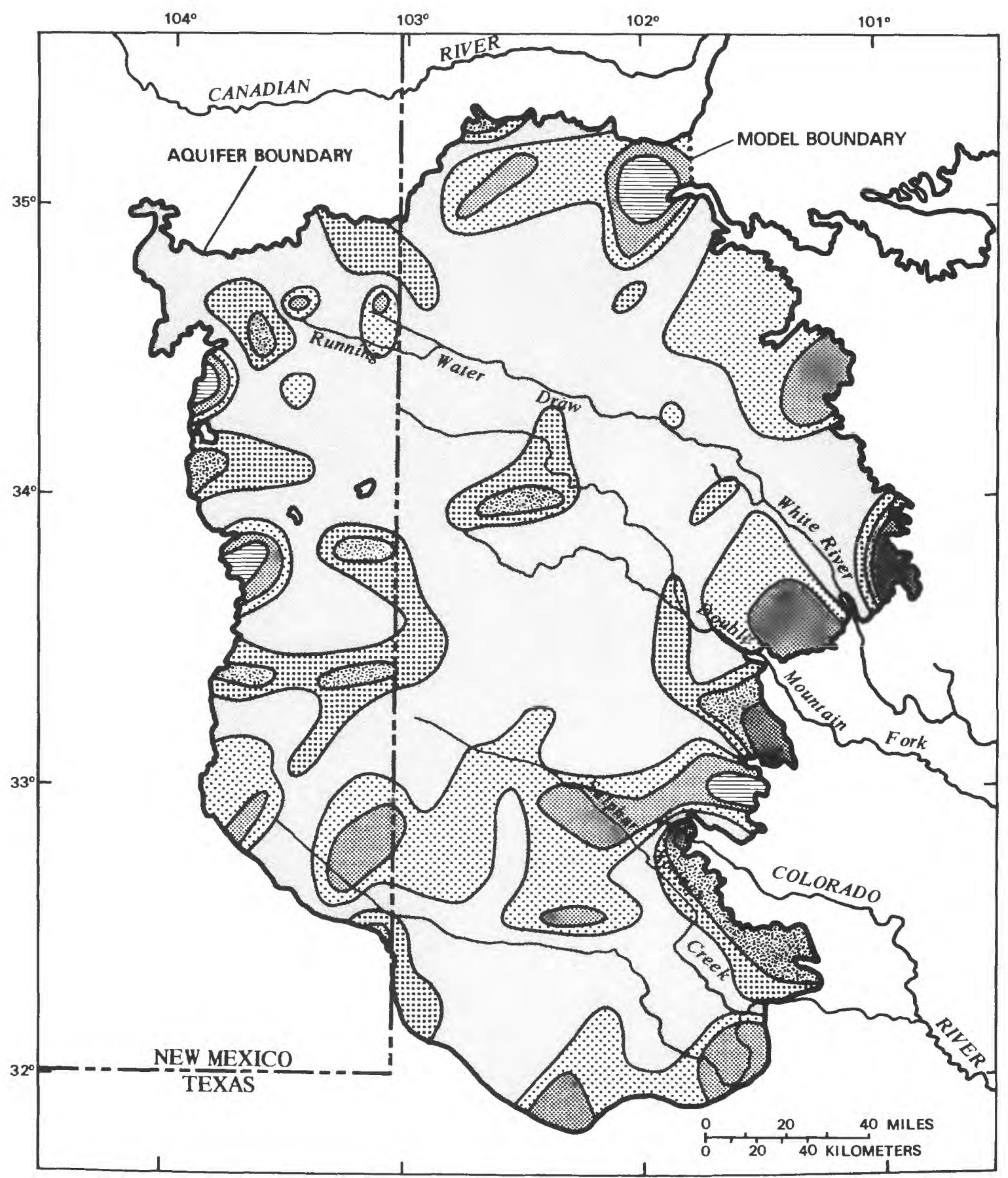

EXPLANATION

DIFFERENCES IN SIMULATED WATER LEVELS BETWEEN FINE-GRID AND AGGREGATED MODELS, IN FEET

\begin{tabular}{ll}
\hline & Difference more than 20 \\
20 to 10 & -5 to -10 \\
10 to 5 & -10 to -20 \\
5 to -5 & Difference less than -20 \\
\hline
\end{tabular}

Figure 9.--Areal distribution of differences in simulated predevelopment water levels between the fine-grid and aggregated models. 
amounts of water for irrigation. Not all of this water was consumed, but part of it returned to the aquifer as increased recharge due to irrigation (return flow). The amount of return flow was the primary value that was varied during the development-period calibration. Return flow was assumed to be a linear function of the difference between total pumpage and the amount of water that the crops required in excess of precipitation (irrigation requirement, Heimes and Luckey, 1982).

The development-period calibration used all of the data from the predevelopment-period calibration. Additional values needed for the developmentperiod calibration included specific yield and net pumpage. The measured 1980 water level was needed for model calibration.

\section{Coarse-Grid Model}

The development-period calibration for the coarse-grid model started with the measured predevelopment (about 1940) water levels and simulated the aquifer system from 1940 to 1980 . Return flow from irrigation was varied during calibration until the best correspondence between the simulated and measured 1980 water-level maps was obtained. Calibration was achieved when return flow was adjusted such that net withdrawal (total pumpage minus return flow) was equal to approximately 90 percent of the estimated irrigation requirement. During the 1960-80 part of the development period, 2 in/yr additional recharge was added to all agricultural land as explained by Luckey and others (1986, p. 18).

For the coarse-grid model, the mean difference between the simulated and measured 1980 water levels was $+0.28 \mathrm{ft}$. The minimum and maximum differences were $-111 \mathrm{ft}$ and $+93 \mathrm{ft}$ respectively. The standard deviation of the differences between the simulated and measured 1980 water levels was $25.8 \mathrm{ft}$, and the mean of the absolute values of the differences was $19.3 \mathrm{ft}$. Figure 10 shows the distribution of the differences between the simulated and measured 1980 water levels for the coarse-grid model.

There were 282 nodes that remained active in the model by 1980 ; the remaining 21 nodes became inactive in the model during the calibration as they became essentially dewatered between 1940 and 1980 . Some of these nodes were within the intensely pumped areas, but many were in areas that had little saturated thickness at the beginning of the simulation period. The total pumpage, return flow, cross-boundary flow, and change in storage for this simulation are summarized in table 3 .

\section{Fine-Grid Model}

The measured 1980 water-level data set used to calibrate the fine-grid model was different from that used to calibrate the coarse-grid model. The data set used to calibrate the coarse-grid model had a mean of $3,501 \mathrm{ft}$ while the data set used to calibrate the fine-grid model had a mean of 3,492 ft. The 9-ft difference in water levels represents about 25 million acrefeet of water or about 12 percent of total pumpage. The 9 -ft difference between these data sets was important because the mean difference between the simulated and measured 1980 water levels was to be the final ("fine-tuned") calibration criterion. 
Table 3.--Water budget for development-period calibration of the fine-grid and coarse-grid models

[Units are in millions of acre-feet]

\begin{tabular}{ccc}
\hline Budget item & Fine-grid model & Coarse-grid model \\
\hline $\begin{array}{l}\text { Outflows: } \\
\text { Tota1 pumpage } \\
\text { Boundary outflow }\end{array}$ & $\begin{array}{r}209.55 \\
4.33\end{array}$ & $\begin{array}{r}209.55 \\
4.11\end{array}$ \\
Total & 213.88 & 213.66 \\
$\begin{array}{l}\text { Inflows : } \\
\text { Return flow from irrigation } \\
\text { Recharge from precipitation } \\
\text { on agricultural land }\end{array}$ & 98.58 & 93.65 \\
$\begin{array}{l}\text { Recharge from precipitation } \\
\text { on rangeland }\end{array}$ & 24.07 & 23.34 \\
$\quad$ Total & 6.32 & 6.38 \\
\hline \begin{tabular}{l} 
Decrease in storage \\
\hline
\end{tabular} & 128.97 & 123.37 \\
\hline
\end{tabular}

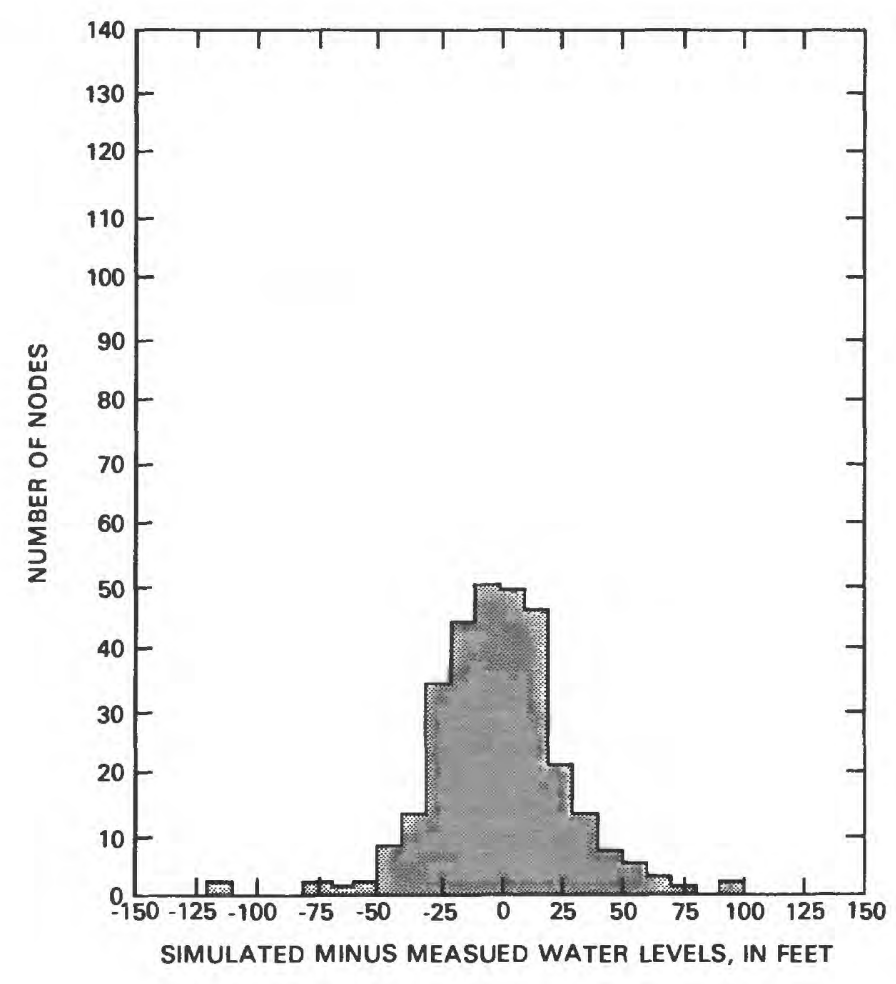

Figure 10.--Differences in simulated and measured 1980 water levels for the coarse-grid model. 
The measured 1980 water-level data sets used to calibrate the coarse-grid model and fine-grid model were examined to determine which better represented the original map. Over approximately the northern one-half of the area, differences between the two data sets appeared random, but in the southern part of the area, there was a bias of up to $20 \mathrm{ft}$ between the two data sets. Such a bias could result from either the coarse grid or the fine grid being shifted or rotated with respect to the original map. The original map had a $100-\mathrm{ft}$ contour interval and was made at a scale of $1: 1,000,000$. The $20-\mathrm{ft}$ bias noted above represented only about 0.11 in. shift of the model grid on the original map. Hence, it was virtually impossible to determine which of the two data sets better represented the original map.

If both models were being recalibrated during this study, the authors would have shifted each of the grids one-half of the difference so that they would be coincident. However, the coarse-grid model was not recalibrated for this study so the "fine-tuned" calibration criterion was changed from a 0.00 $\mathrm{ft}$ residual to $8.07 \mathrm{ft}$ residual. The $8.07 \mathrm{ft}$ residual is the result of a $+8.94 \mathrm{ft}$ difference in the measured 1980 water-level data sets and a $-0.87 \mathrm{ft}$ difference in the measured 1940 water-level data sets. With an $8.07 \mathrm{ft}$ residual, the fine-grid model and coarse-grid model would have the same change in ground-water storage from 1940 to 1980 and approximately the same 1980 water level. The change in calibration criteria would overcompensate in the northern part of the area and undercompensate in the southern part. However, this overcompensation and undercompensation would be small compared to the contour interval on the original map.

The model was considered calibrated when return flow was adjusted such that net pumpage was 86 percent of the estimated irrigation requirement. The total pumpage for this simulation was 210 million acre-feet, and return flow was 99 million acre-feet (table 3 ).

The simulated and measured 1980 water levels for the calibrated fine-grid model are shown in figure 11. There is a reasonable correspondence between the shapes of the contours. The mean difference between the two surfaces is $8.22 \mathrm{ft}$. The "fine-tuned" calibration criterion was $8.07 \mathrm{ft}$, so this criterion was missed by $0.15 \mathrm{ft}$. The minimum and maximum differences between the two surfaces was -92 and $+166 \mathrm{ft}$ respectively for the 1,201 nodes. The standard deviation of the difference between the simulated and measured 1980 water levels was $27.9 \mathrm{ft}$, and the mean of the absolute values of the differences was $21.5 \mathrm{ft}$. The statistics for the development-period calibration of both the coarse-grid model and the fine-grid model are summarized in table 4.

As was done with the predevelopment period, the simulated 1980 water levels from the fine-grid model were aggregated by taking an arithmetic average of the simulated 1980 water levels at (up to four) nodes from the fine-grid model that corresponded to one node in the coarse-grid model. A node-by-node comparison was made between the simulated 1980 water levels from the fine-grid model and the coarse-grid model. The mean difference in 1980 water levels from the fine-grid model and coarse-grid model was $1.43 \mathrm{ft}$ with a standard deviation of $21.8 \mathrm{ft}$. A histogram of the differences between the 


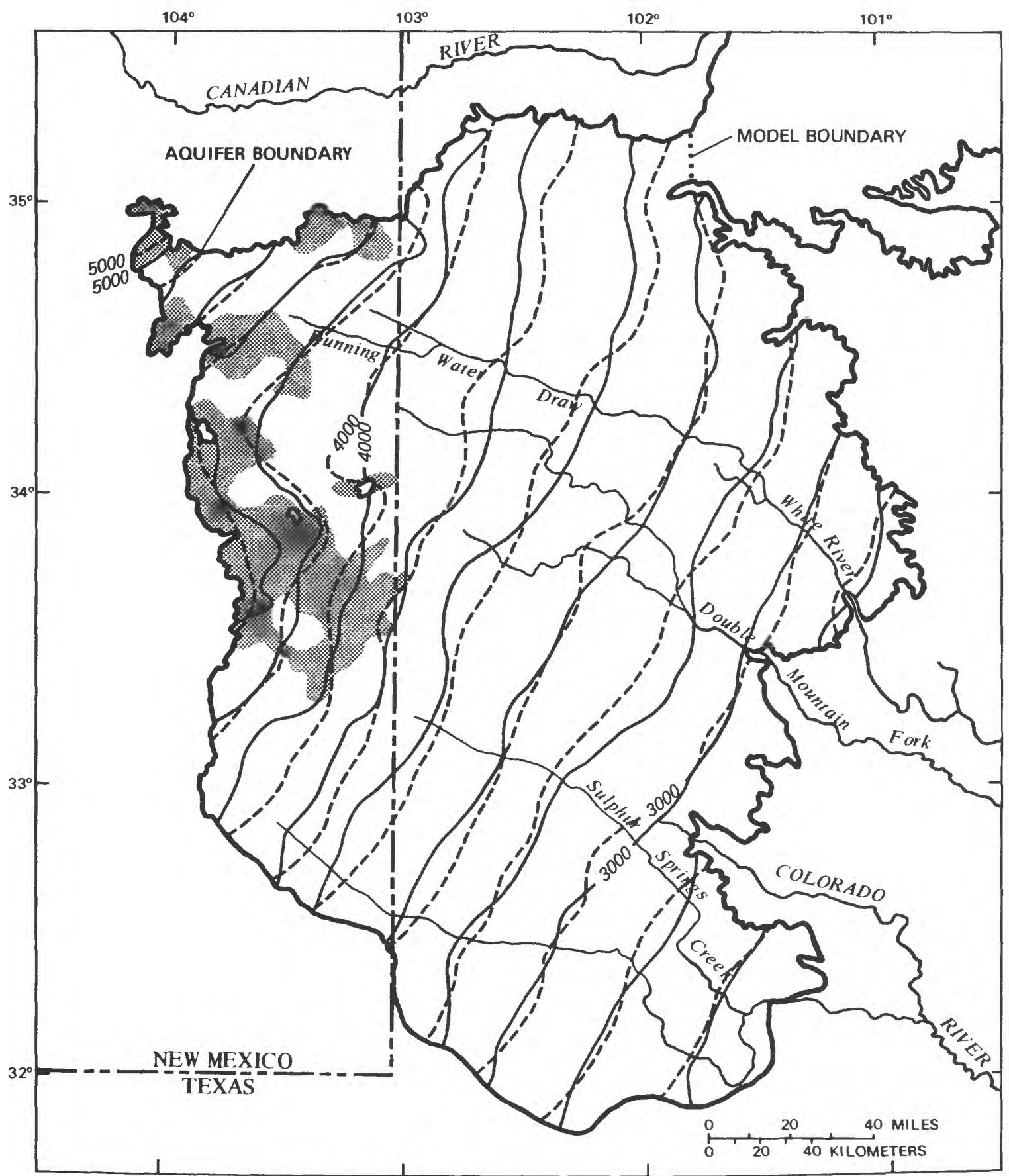

EXPLANATION

AREA OF LITTLE OR NO SATURATED THICKNESS

PREDEVELOPMENT WATER LEVEL CONTOUR -

Contour interval is 200 feet. Datum is sea level

$\begin{array}{ll}--4000-- & \text { Measured } \\ -4000- & \text { Simulated }\end{array}$

Figure 11.--Simulated and measured 1980 water levels for the fine-grid model. 
Table 4.--Model statistics for development-period calibration of the fine-grid and coarse-grid models

[Units are as indicated]

\begin{tabular}{|c|c|c|}
\hline Statistic & Fine-grid model & Coarse-grid model \\
\hline \multicolumn{3}{|l|}{ Number of active nodes at } \\
\hline calibration & 1,201 & 282 \\
\hline Size of node (square miles) & 25 & 100 \\
\hline \multicolumn{3}{|l|}{ Residual ${ }^{1}$ from calibration } \\
\hline criterion (feet) & +0.15 & +0.28 \\
\hline Mean difference ${ }^{2}$ (feet) & +8.22 & +0.28 \\
\hline \multicolumn{3}{|l|}{ Standard deviation of } \\
\hline differences ${ }^{2}$ (feet) & 27.9 & 25.8 \\
\hline \multicolumn{3}{|l|}{ Mean of absolute value of } \\
\hline differences ${ }^{2}$ (feet) & 21.5 & 19.3 \\
\hline Most negative difference ${ }^{2}$ (feet) & -99 & -111 \\
\hline Most positive difference ${ }^{2}$ (feet) & +160 & +93 \\
\hline
\end{tabular}
sought.

${ }^{1}$ Residual refers to the mean difference at calibration and the mean difference

${ }^{2}$ Difference refers to the measured 1980 water level minus the simulated 1980 water level.

simulated 1980 water levels from the two models is shown in figure 12 . Two nodes had negative differences of more than $-50 \mathrm{ft}$ and six nodes had positive differences of more than $+50 \mathrm{ft}$. At 90 percent of the nodes, the absolute values of the differences between the two models were less than $30 \mathrm{ft}$ and at 73 percent of the nodes, the absolute values of the differences were less than $20 \mathrm{ft}$.

The areal distribution of the differences between the simulated 1980 water levels from the fine-grid model and coarse-grid model is shown in figure 13. The largest area of negative difference is in the northern part of the southern High Plains while the largest area of positive difference is in the southern part. There appears to be no hydrologic significance to the differences. Comparing the differences in this figure with the differences shown in figure 6 , the areas of positive difference in this map roughly correspond to areas of negative difference in the previous map and vice versa. Hence, there does not seem to be any consistent pattern of differences between the coarse-grid model and fine-grid model for either the predevelopment-period or development-period calibration.

Table 5 lists the simulated 1980 water levels for the fine-grid model and coarse-grid model for those nodes which had the most positive and most negative differences between the two models. The location of these nodes is shown in figure 14. These nodes are less than the fifth percentile and greater than the ninety-fifth percentile of the differences and represent 10 percent of the model area. The 1940 water level (the initial water level) and the specific yield are also shown for these nodes because the simulated 1980 


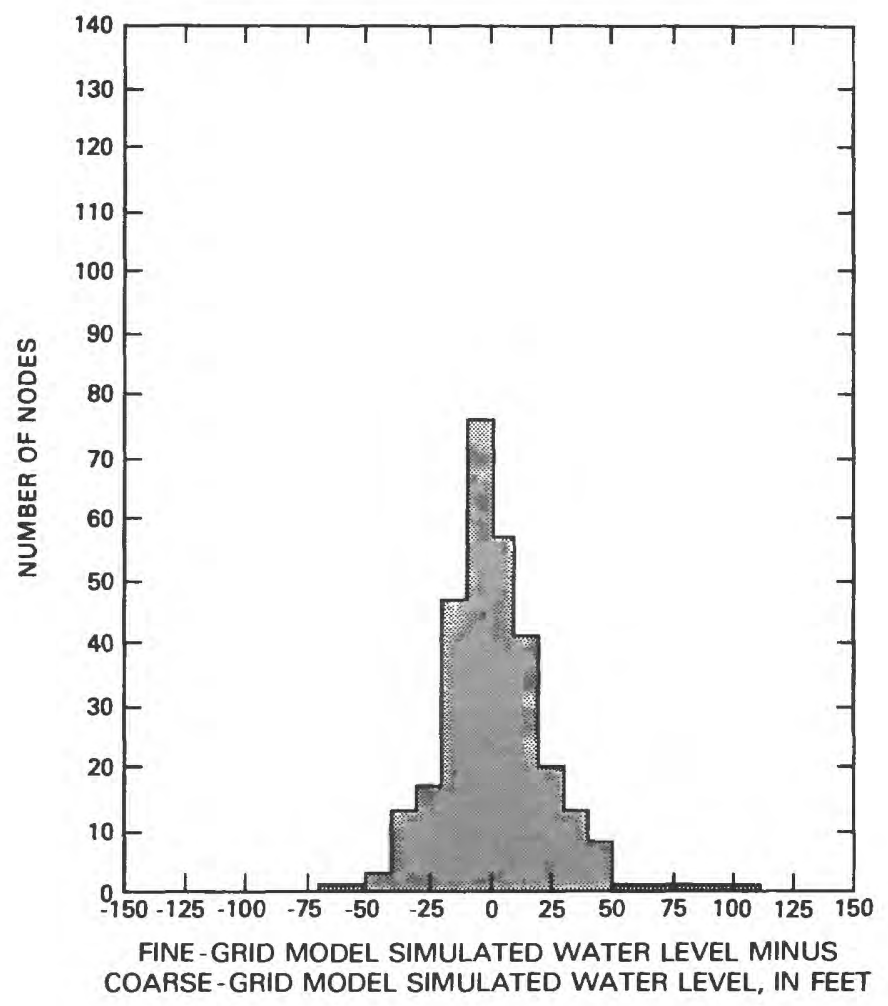

Figure 12.--Differences in simulated 1980 water levels between the fine-grid and coarse-grid models.

water levels are sensitive to these two values. The table shows that, for the most part, the specific yield in the coarse-grid model and the fine-grid model were similar. The 1940 water level was also similar at most nodes. An exception is the node number 29 in the table. However, this node is at the edge of the model in an area where water level values are extremely difficult to determine.

\section{Aggregated Model}

After calibration of the development-period fine-grid model, the values were aggregated to $100-\mathrm{mi}^{2}$ grids. The method of aggregating the data was identical to that used for the predevelopment period. The development-period aggregated model was used to simulate the 1980 water level using values as close to those used in the fine-grid model as the grid would permit. Because of the slight differences in boundaries between the models, the pumpage in the aggregated model was 0.26 percent greater than in the fine-grid model.

Similarly, total recharge was 3.9 percent greater in the aggregated model even though recharge at individual nodes was identical. The mean differences between the simulated and measured 1980 water levels for the aggregated model was $8.50 \mathrm{ft}$ compared to $8.22 \mathrm{ft}$ for the fine-grid model. 


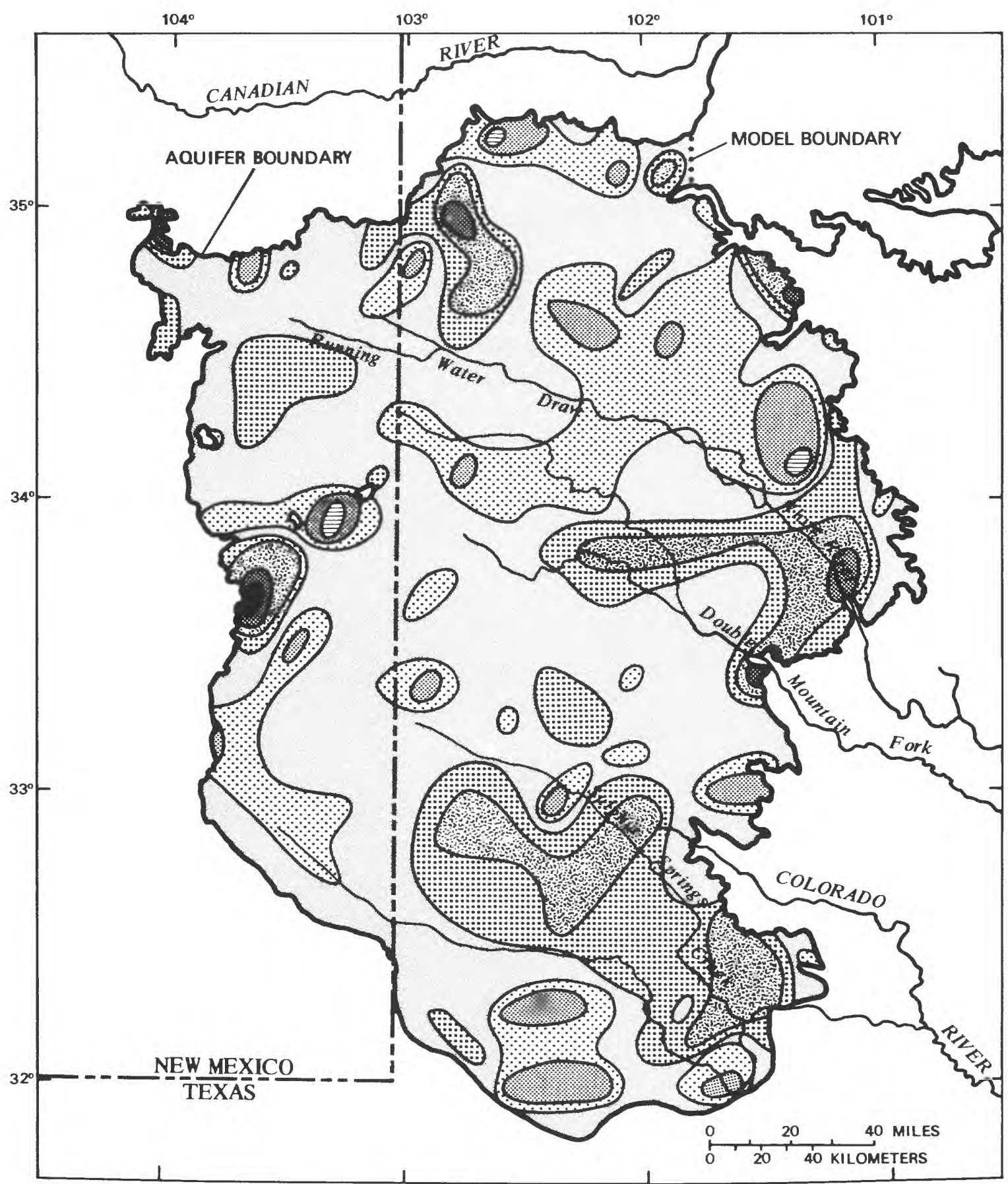

EXPLANATION

DIFFERENCES IN SIMULATED WATER LEVELS BETWEEN FINE-GRID AND COARSE-GRID MODELS, IN FEET

\begin{tabular}{|c|c|}
\hline Difference more than 100 & 10 to -10 \\
\hline 100 to 50 & -10 to -25 \\
\hline 50 to 25 & -25 to -50 \\
\hline 25 to 10 & Difference less than -50 \\
\hline
\end{tabular}

Figure 13.--Areal distribution of differences in simulated 1980 water levels between the fine-grid and coarse-grid models. 


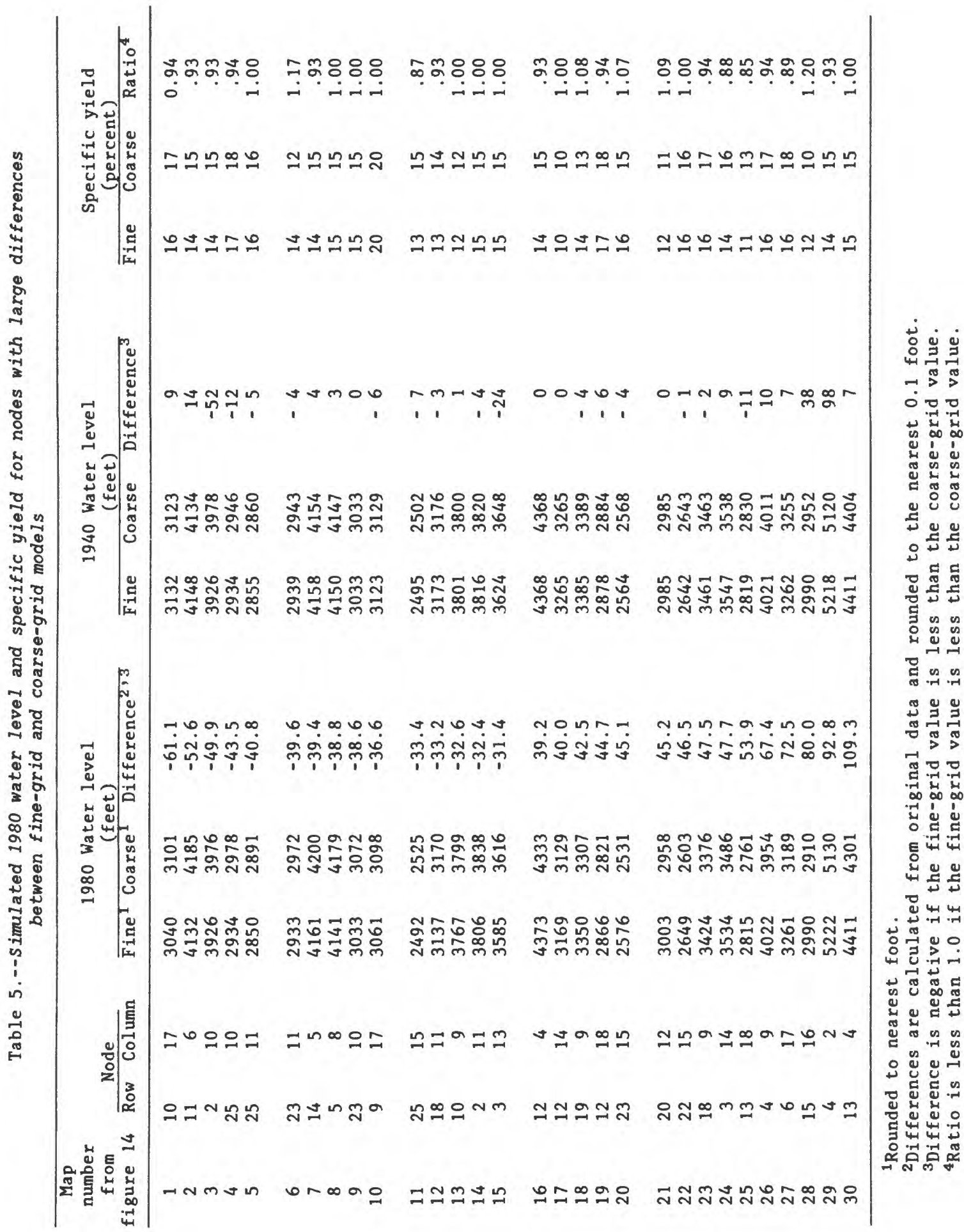




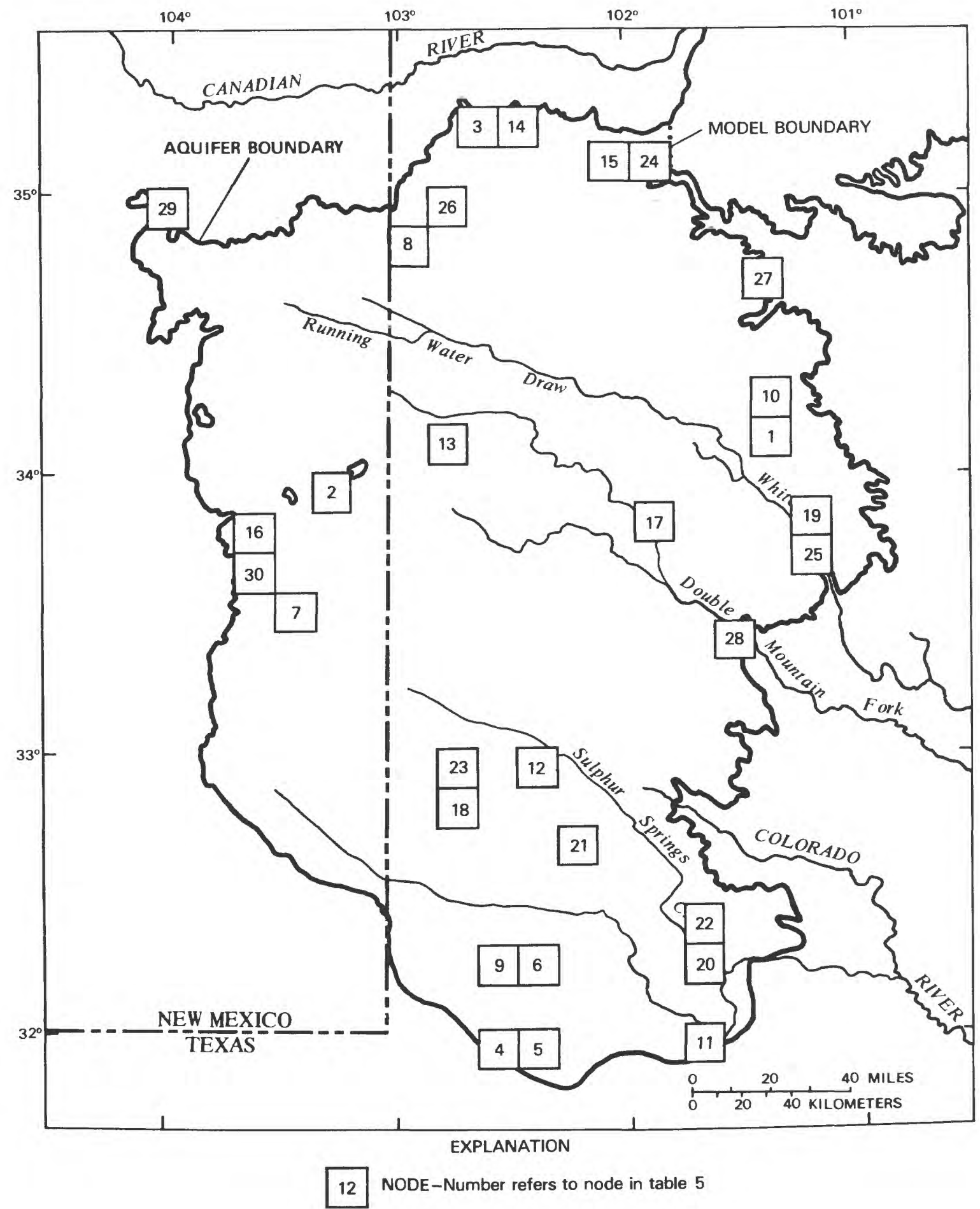

Figure 14.--Location of nodes with large differences in simulated 1980 water levels between the fine-grid and coarse-grid models. 
The simulated 1980 water levels for the fine-grid model and aggregated model were compared on a node-by-node basis. A histogram of the differences in simulated 1980 water levels between the models is shown in figure 15 . The differences ranged from $-18 \mathrm{ft}$ to $+17 \mathrm{ft}$ and averaged $0.39 \mathrm{ft}$. The standard deviation of the differences was $4.4 \mathrm{ft}$. At 90 percent of the nodes, the differences were less than $6.5 \mathrm{ft}$ and at 80 percent of the nodes, the differences are less than $4.7 \mathrm{ft}$. This histogram should be compared to the differences between the simulated and measured 1980 water levels for the coarse-grid model (fig. 2). As can be seen in this comparison, the discretization difference between the $100-\mathrm{mi}^{2}$ and $25-\mathrm{mi}^{2}$ grids is small compared to the differences between the simulated and measured 1980 water levels.

The areal distribution of the differences between the fine-grid model and aggregated model is shown in figure 16. Over most of the area, the difference between the two models was less than $5 \mathrm{ft}$. There were some small areas where the differences were larger than $10 \mathrm{ft}$. Most of these areas were concentrated along the eastern boundary, where the location of the boundary between the two models was different. The area of +5 to $+10 \mathrm{ft}$ difference just south of Double Mountain Fork at about $102^{\circ}$ longitude is the largest area of



Figure 15.--Differences in simulated 1980 water levels between the fine-grid and aggregated models. 


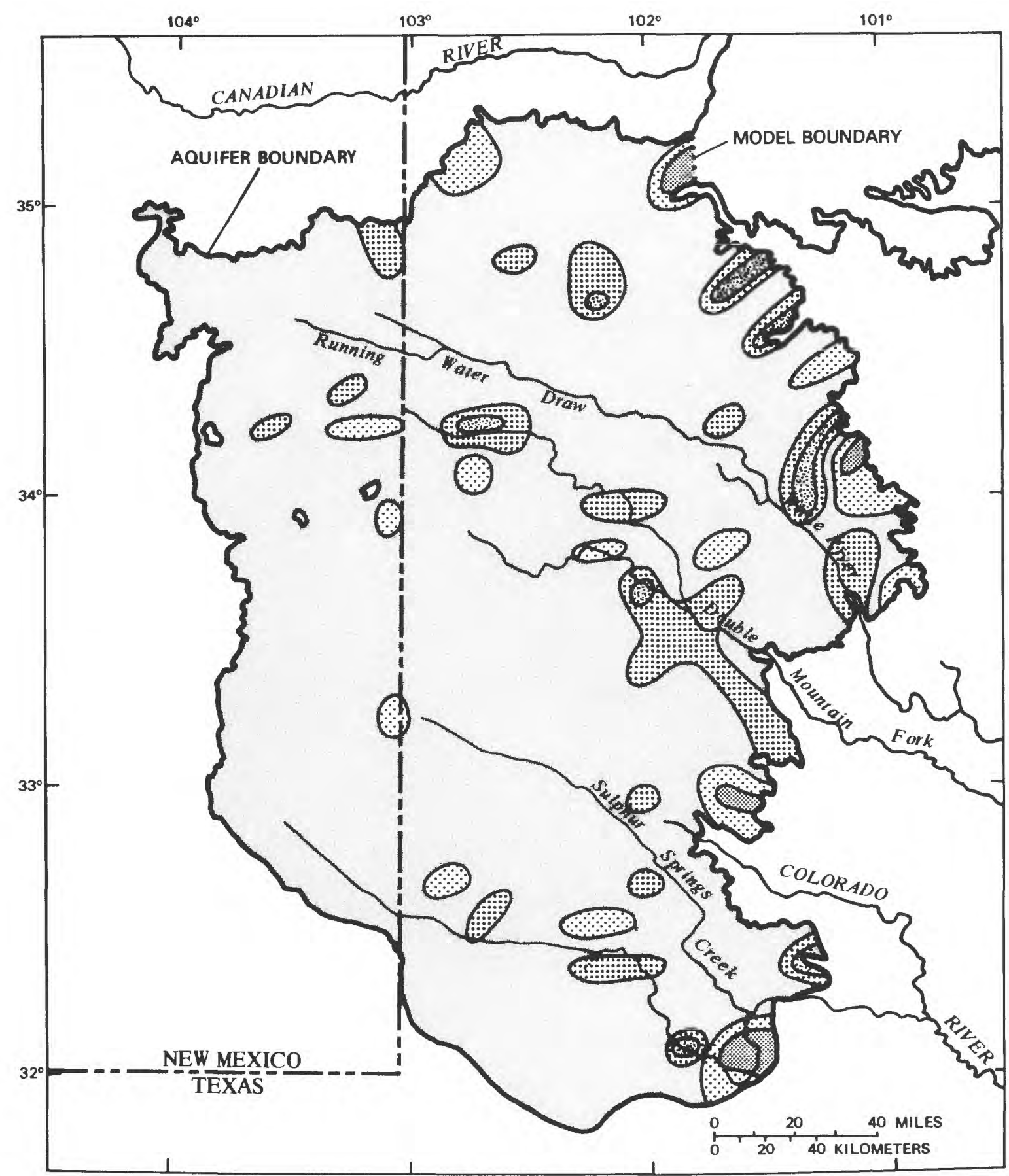

EXPLANATION

DIFFERENCES IN SIMULATED WATER LEVELS BETWEEN FINE-GRID AND AGGREGATED MODELS, IN FEET

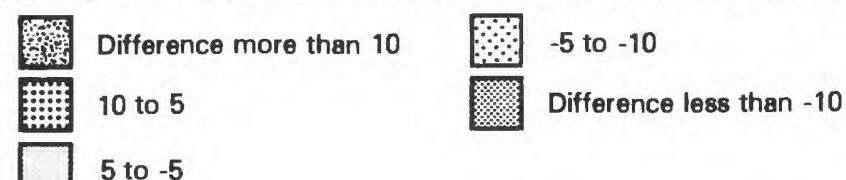

Figure 16.--Areal distribution of differences in simulated 1980 water levels between the fine-grid and aggregated models. 
difference. The specific yield in this area is not any more variable than it is across the rest of the southern High Plains. Pumpage in this area is not particularly large, especially when compared to the area further north. Hence, if there is any hydrologic significance to the difference between the fine-grid model and aggregated model in this area, it is not apparent.

\section{SUMMARY AND CONCLUSIONS}

Three models of the aquifer in the southern High Plains were used to determine the effect of grid size on the models. The coarse-grid model had $10-\mathrm{mi}$ node spacing $\left(100-\mathrm{mi}^{2}\right.$ grids). This was the original model that was constructed and calibrated prior to this study. The fine-grid model had $5-\mathrm{mi}$ node spacing $\left(25-\mathrm{mi}^{2}\right.$ grids). It was constructed and calibrated in this study independently of the coarse-grid model. The same original maps were used to generate the data used to construct these two models, but the data differed somewhat between the models because of differences in visual

interpolation. The aggregated model was constructed by aggregating the data from the fine-grid model to $100-\mathrm{mi}^{2}$ grids. The data used for the aggregated model were as close to those for the fine-grid model as the grid would permit.

The distribution of recharge as determined with the predevelopment-period coarse-grid model and fine-grid model was the same. The total recharge differed by less than 1 percent between the two models. The mean difference in predevelopment water levels was $-1.09 \mathrm{ft}$ with a standard deviation of $19.0 \mathrm{ft}$. The simulated water levels differed between the two models in some areas, but these differences did not seem to have any hydrologic significance.

The development-period coarse-grid model was calibrated using a net pumpage (total pumpage minus return flow) that was 90 percent of the estimated irrigation requirement. The development-period fine-grid model was calibrated using a net pumpage that was 86 percent of the estimated irrigation requirement. For practical purposes, the difference between these results is not significant. The two models differed in simulated 1980 water levels in some areas but these differences did not seem to have any hydrologic significance.

While calibrating the fine-grid model, it was learned that there is far more potential for error in developing the data set that will be used for calibration than the error caused only by using a larger grid size. It is extremely important to have accurate data for the model and if the accuracy of the data (particularly those items to which the model is sensitive) requires a larger than optimal grid spacing, then sacrificing small grid spacing to achieve accurate model inputs would be a good choice for the type of hydrologic system in this study.

Comparison of results from the coarse-grid model and fine-grid model indicated that the same general hydrologic conclusions would have been reached as a result of model calibration based on data that were available at the time the original model was calibrated whether $25-\mathrm{mi}^{2}$ grids or $100-\mathrm{mi}^{2}$ grids were used. 
The predevelopment-period aggregated model calculated water levels very close to those calculated with the fine-grid model. The mean difference between the water levels was $0.86 \mathrm{ft}$ with a standard deviation of $8.9 \mathrm{ft}$. The differences ranged from $-35 \mathrm{ft}$ to $+36 \mathrm{ft}$. Most of the larger differences occurred near the boundary of the aquifer, but some occurred in areas where the hydraulic conductivity changed rapidly over short distances.

The development-period aggregated model calculated 1980 water levels that also were very close to those calculated with the fine-grid model. The mean difference was $0.39 \mathrm{ft}$ with a standard deviation of $4.4 \mathrm{ft}$. The differences ranged from -18 to $+17 \mathrm{ft}$. Most of the larger differences occurred near the boundary of the aquifer.

If $25-\mathrm{mi}^{2}$ grids had been used in the original model of the aquifer in the southern High Plains instead of $100-\mathrm{mi}^{2}$ grids, the same general conclusions about the operation of the hydrologic system would have been reached. Slightly different estimates would have been made for recharge and net pumpage. The differences between the simulated and measured water levels were much larger than the differences between the simulated water levels between models using $25-\mathrm{mi}^{2}$ and $100-\mathrm{mi}^{2}$ grids. For the predevelopment-period fine-grid model, the standard deviation of the difference between the simulated and measured predevelopment water levels was $44.4 \mathrm{ft}$. The standard deviation of the difference between the simulated predevelopment water levels from the fine-grid model and aggregated model was $8.9 \mathrm{ft}$. Similar results were obtained for the 1980 water levels where the respective standard deviations were $27.9 \mathrm{ft}$ and $4.4 \mathrm{ft}$. 


\section{REFERENCES CITED}

Finch, W.I., and Wright, J.C., 1970, Linear features and ground-water distribution in the Ogallala Formation of the southern High Plains, in Mattox, R.B., and Miller, W.D., eds., Ogallala Aquifer Symposium: Texas Tech University, Lubbock, 1970, International Center for Arid and Semiarid Land Studies Special Report 39, p. 49-57.

Gutentag, E.D., Heimes, F.J., Krothe, N.C., Luckey, R.R., and Weeks, J.B., 1984, Geohydrology of the High Plains aquifer in parts of Colorado, Kansas, Nebraska, New Mexico, Oklahoma, South Dakota, Texas, and Wyoming: U.S. Geological Survey Professional Paper 1400-B, 63 p.

Heimes, F.J., and Luckey, R.R., 1982, Method for estimating historical irrigation requirements from ground water in the High Plains in parts of Colorado, Kansas, Nebraska, New Mexico, Oklahoma, South Dakota, Texas and Wyoming: U.S. Geological Survey Water-Resources Investigations $82-40,64 \mathrm{p}$.

Luckey, R.R., Gutentag, E.D., and Weeks, J.B., 1981, Water-level and saturated-thickness changes, predevelopment to 1980, in the High Plains aquifer in parts of Colorado, Kansas, Nebraska, New Mexico, Oklahoma, South Dakota, Texas, and Wyoming: U.S. Geological Survey Hydrologic Investigations Atlas HA-652.

Luckey, R.R., Gutentag, E.D., Heimes, F.J., and Weeks, J.B., 1986, Digita1 simulation of ground-water flow in the High Plains aquifer in parts of Colorado, Kansas, Nebraska, New Mexico, Oklahoma, South Dakota, Texas, and Wyoming: U.S. Geological Survey Professional Paper 1400-D, 57 p.

Trescott, P.C., Pinder, G.F., and Larson, S.P., 1976, Finite-difference model for aquifer simulation in two dimensions with results of numerical experiments: U.S. Geological Survey Techniques of Water Resources Investigations, Book 7, Chapter C1, $115 \mathrm{p}$.

U.S. Geological Survey, 1984, National water summary 1983--hydrologic events and issues: U.S. Geological Survey Water-Supply Paper 2250, 243 p.

Weeks, J.B., 1978, Plan of study for the High Plains regional aquifer-system analysis in parts of Colorado, Kansas, Nebraska, New Mexico, Oklahoma, South Dakota, Texas, and Wyoming: U.S. Geological Survey WaterResources Investigations 78-70, $28 \mathrm{p}$.

Wood, W.W., and Osterkamp, W.R., 1984, Recharge to the Ogallala aquifer from playa lake basins on the Llano Estacado (an outrageous proposal?), in Whetstone, George A., ed., Proceedings of the Ogallala aquifer symposium II: Texas Tech University Water Resources Center, Lubbock, Tex., p. 337-349. 